\title{
AUTIZAM I SAMOPERCEPCIJA ZNANJA POMOĆNIKA U NASTAVI
}

\section{AUTISM AND SELF-PERCEIVED KNOWLEDGE OF THE LEARNING SUPPORT ASSISTANTS}

\author{
DENIS JURKOVIĆ ${ }^{1}$, ANITA PENIĆ JURKOVIĆ, IVA MAGLIĆ \\ ${ }^{1}$ Odjel za nastavničke studije u Gospiću, Sveučilište u Zadru, \\ contact:djurkovic@unizd.hr
}

Primljeno/Received: 04.09.2020.

Prihvaćeno/Accepted: 01.12.2020.
Izvorni znanstveni rad/Original research article UDK: 376-057.164:616.896 doi: $10.31299 /$ hrri.56.2.8
Sažetak: Cilj istraživanja provedenog u šk. god. 2019/2020. na uzorku od 425 pomoćnika u nastavi bio je ustanoviti razinu samoprocijenjenog znanja o inkluziji te radu s učenicima s autizmom među pomoćnicima $u$ nastavi. Također cilj istraživanja bio je i ustanoviti koji od sociodemografskih pokazatelja pridonose samoprocjeni znanja o radu s učenicima s autizmom, ali i inkluziji općenito. Za potrebe ovog istraživanja osmišljen je upitnik Samoprocjene znanja o inkluziji i autizmu (SZIA) koji se sastoji od 2 subskale. Prva subskala, Samoprocjena specifičnih znanja o autizmu, mjeri samoprocijenjeno znanje o radu s učenicima s autizmom, dok druga, Samoprocjena općih znanja o inkluziji, mjeri samoprocijenjeno znanje pomoćnika u nastavi o inkluziji općenito. Sastavljen je i Sociodemografski upitnik kojim su prikupljeni ostali podaci o sudionicima istraživanja. Prema dobivenim rezultatima početni motiv za rad te godine rada s učenicima s autizmom statistički su značajno pozitivno povezane, a završena edukacija za pomoćnika u nastavi te iskustvo rada s ovim učenicima statistički su značajno negativno povezani sa samoprocjenom znanja o radu s učenicima s autizmom, no nemaju bitnu ulogu $u$ samoprocjeni znanja o inkluziji. Također među sudionicima istraživanja postoje statistički značajne razlike pri samoprocjeni znanja o radu s učenicima s autizmom. To se posebice odnosi na početni motiv za rad, završenu edukaciju za pomoćnika u nastavi te iskustvo rada $s$ učenicima s autizmom, dok godine rada u ulozi pomoćnika ne čine statistički značajnu razliku. Na koncu pokazalo se $i$ da samoprocijenjeno znanje o inkluziji statistički značajno pridonosi samoprocijenjenom znanju o radu s učenicima $s$ autizmom. Ovakva istraživanja imaju izuzetan potencijal za

\begin{abstract}
The aim of this e-research carried out in the school year 2019/2020, on a sample of 425 learning support assistants, was to establish the level of self-perceived knowledge about inclusion and working with students with autism among learning support assistants. The aim of the research was also to establish which of the socio-demographic indicators contribute to self-perceived knowledge about working with students with autism, but also to inclusion in general. The Questionnaire on the Self-Perceived Knowledge on Inclusion and Autism (SZIA), which consists of two subscales, was designed for the purposes of this research. The first subscale, Self-perceived specific knowledge on autism, measures self-perceived knowledge on working with students with autism; while the other subscale, Self-perceived general knowledge on inclusion, measures self-perceived knowledge of the learning support assistant on inclusion in general. A socio-demographic questionnaire was also compiled by which other data on research participants were collected. According to the obtained results, self-perceived knowledge about working with students with autism showed a statistically significant positive relationship with the initial motive for working with those students. Completion of training for becoming a learning support assistant and experience in working with those students showed a significant negative relationship with self-perceived knowledge about working with students with autism. However, neither motive, training nor experience played an essential role in self-perceived knowledge about inclusion. Also, there were statistically significant differences among study participants in self-perceived knowledge about working with students with autism. This applies in particular to the initial motive for work, completed training for learning support assistant and the experience of working with students with autism, while years of work as an assistant did not make a statistically significant difference. Finally, self-perceived knowledge on inclusion was shown to contribute
\end{abstract}


dobivanje boljeg uvida u znanja i kompetencije pomoćnika, a samim tim $i$ u kvalitetu rada istih.

Ključne riječi: pomoćnici u nastavi, samoprocjena znanja, inkluzija, autizam, edukacija

\section{UVOD}

Inkluzija podrazumijeva uključivanje djece i mladih s teškoćama u razvoju u redovne razrede, zajedno s djecom urednog razvoja. Inkluzivna učionica ima brojne prednosti za učenike s teškoćama. Primjerice imaju više prilika za razvoj prijateljstava, vršnjaci im postaju model za uvježbavanje akademskih vještina te im je omogućen bolji pristup općem kurikulumu. Osim toga inkluzivno obrazovanje nije korisno samo za njih, nego i za njihove vršnjake jer se uče poštivanju različitosti te se pripremaju za život u raznolikoj zajednici (Hayes, Baylot, Williamson, Black i Winsor, 2013). $\mathrm{U}$ redovne se razrede sve više uključuju djeca $\mathrm{s}$ poremećajima iz spektra autizma budući da se smatra da isto dovodi do poboljšanja njihove kvalitete života, socijalnog razvoja i izvedbe u akademskom smislu (Knight i sur., 2009; prema Osborne i Reed, 2011). Humphrey i Lewis (2008; prema Symes i Humphrey, 2012) inkluziju učenika s poremećajem iz spektra autizma u redovne škole navode kao najkompleksnije područje obrazovanja koje se i najmanje razumije.

Poremećaji iz spektra autizma ubrajaju se u neurorazvojne poremećaje, a karakterizira ih oštećenje mnogih razvojnih funkcija, posebice problemi socijalizacije i adekvatne komunikacije, no i pojavljivanje stereotipnih oblika ponašanja, aktivnosti i interesa (Ljubičić, Šare i Markulin, 2014). Smatra se globalnim razvojnim poremećajem koji se može javiti već u prvim godinama života i trajati cijeli život (Bujas-Petković, 1995). Većinom roditelji, već nakon rođenja djeteta, zapažaju atipična ponašanja i poteškoće s kojima se ono suočava, no do postavljanja ispravne dijagnoze zna proći i nekoliko godina što uvelike utječe na obiteljsku strukturu i kvalitetu života, prvenstveno djeteta, ali i njegovih roditelja (Špelić statistically significantly to self-perceived knowledge of working with students with autism. This kind of research has great potential for gaining a better insight into the knowledge and competencies of assistants, and thus the quality of their work.

Keyword: learning support assistant, self-perceived knowledge, inclusion, autism, training

\section{INTRODUCTION}

Inclusion implies the inclusion of children and young people with development disabilities in regular classes, together with children who develop typically. An inclusive classroom has a number of benefits for students with disabilities. For instance, they have more opportunities to develop friendships, their peers become a model for them for practising academic skills, and they are given greater access to the general curriculum. In addition to that, inclusive education is beneficial not only for them, but also for their peers because they learn to respect diversity and prepare for life in a diverse community (Hayes, Baylot, Williamson, Black, \& Winsor, 2013). Children with autism spectrum disorders are increasingly included in regular classes since it is thought that it leads to an improvement in their quality of life, social development and academic performance (Knight et al., 2009; according to Osborne and Reed, 2011). Humphrey and Lewis (2008; according to Symes and Humphrey, 2012) cite the inclusion of students with autism spectrum disorder in regular schools as the most complex area of education, and the least understood.

Autism spectrum disorders are neurodevelopmental disorders, and they are characterized by impairment of many developmental functions, especially problems regarding the socialisation and adequate communication, but also the emergence of stereotypical forms of behaviour, activities and interests (Ljubičić, Šare and Markulin, 2014). It is considered a global developmental disorder that can occur in the first years of life and last a lifetime (Bujas-Petković, 1995). Parents mostly, already after birth, notice atypical behaviours and difficulties that their child faces, but it can take several years to make a correct diagnosis, which greatly affects the family structure and quality of life, primarily of the child, but also of his or her parents (Špelić and 
i Košeto, 2012). Poteškoće s kojima se suočava dijete s autizmom i njegova obitelj nastavljaju se i kasnije, pri ulasku u odgojno-obrazovni sustav. Naime djeca s poremećajem iz spektra autizma $u$ redovnim razredima mogu doživjeti poteškoće u stjecanju i održavanju prijateljstava, ograničenu reakciju na verbalnu pohvalu, poteškoće u razumijevanju drukčijih stavova što otežava sudjelovanje u grupnom radu, poteškoća u shvaćanju smisla društvenog okruženja, kao i poteškoća s manje strukturiranim dijelovima dana u školi (Hampshire County Council Childrens Services Department SEN Service, 2010; prema Lombardi, 2016). Upravo im je zato potrebna obuhvatna pomoć pri prevladavanju takvih teškoća. Štoviše, integracija učenika s poremećajem iz autističnog spektra u redovni odgojno-obrazovni program zahtjeva zadovoljavanje uvjeta i omogućavanje specifičnih metoda prilagođenih potrebama učenika i sukladno važećim zakonskim propisima (Zrilić, 2013). Prema Okviru za poticanje i prilagodbu iskustava učenja te vrednovanje postignuća učenika s teškoćama (Ustav Republike Hrvatske, članak 64.) svaka odgojno-obrazovna ustanova obvezna je osigurati uvjete i omogućiti izradu osobnog kurikuluma sukladno specifičnim odgojno-obrazovnim potrebama učenika s teškoćama. Neke od prilagodbi pristupa učenja i poučavanja učenika s poremećajima iz spektra autizma odnose se na upotrebljavanje vizualnog rasporeda, uvođenja vizualne podrške pri ovladavanju sadržajem, omogućavanje zamjenskih aktivnosti, osiguranje pomoćnika u nastavi itd. Da bi inkluzija bila uspješna, škola se mora prilagoditi potrebama djece umjesto očekivati da će se učenik uklopiti u postojeće rutine i procese (Batten, 2005; prema Symes i Humphrey, 2012).

Osiguravanje potpore pomoćnika u nastavi jedan je od oblika prilagodbe individualnim potrebama učenika, čiji je cilj izjednačavanje mogućnosti svih učenika. Prema Pravilniku o pomoćnicima u nastavi i stručnim komunikacijskim posrednicima (2018), pomoćnik u nastavi definira se kao "osoba koja pruža neposrednu potporu učeniku tijekom odgojno-obrazovnoga procesa u zadacima koji zahtijevaju komunikacijsku, senzornu i motoričku aktivnost učenika, u kretanju, pri uzimanju hrane i pića, u obavljanju
Košeto, 2012). The difficulties faced by a child with autism and his family continue later on, when the child enters the educational system. Namely, children with autism spectrum disorder in regular classes may experience difficulties in making and maintaining friendships, show limited reaction to verbal praise, and experience difficulties in understanding different views, which in turn leads to difficulties in group cooperation, difficulties in understanding the meaning of the social world and difficulties with less structured parts of the day at school (Hampshire County Council Childrens Services Department SEN Service, 2010; according to Lombardi, 2016). That is why they need comprehensive help in overcoming such difficulties. Moreover, the integration of students with autism spectrum disorder into the regular educational programme requires meeting the conditions and enabling specific methods adapted to the needs of students and in accordance with applicable legislation (Zrilić, 2013). According to the Framework for Encouraging and Adapting Learning Experiences and Evaluation of Achievements of Students with Disabilities (Constitution of the Republic of Croatia, Article 64), every educational institution is obliged to provide conditions and to enable the development of a personal curriculum in accordance with specific educational needs of students with disabilities. Some of the adaptations of the approach to learning and teaching students with autism spectrum disorders relate to the use of visual scheduling, the introduction of visual support in mastering content, enabling substitute activities, and providing learning support assistants. In order for inclusion to be successful, the school must adapt to the needs of children instead of expecting the student to fit into existing routines and processes (Batten, 2005; according to Symes and Humphrey, 2012).

Providing the support of learning support assistants is one of the forms of adaptation to the individual needs of students, the goal of which is to equalise the possibilities of all students. According to the Ordinance on Teaching Assistants and Professional Communication Mediators (2018), a learning support assistant is defined as "a person who provides direct support to a student during the educational process in tasks that require communication, sensory and motor activity of students, when moving, when eating and drinking, in performing hygienic needs, 
higijenskih potreba, u svakodnevnim nastavnim, izvannastavnim i izvanučioničkim aktivnostima, a sve prema izrađenom programu rada prema utvrđenim funkcionalnim sposobnostima i potrebama svakoga pojedinog učenika te uputama učitelja/ nastavnika, stručnih suradnika škole, odnosno stručnoga tima". Pomoćnici u nastavi jedni su od najvažnijih nositelja inkluzije djece s poremećajem iz spektra autizma i imaju važnu ulogu u njihovom obrazovanju. Oni učenicima pružaju osjećaj dosljednosti koja im je prijeko potrebna, posebice u situacijama kada se mijenjaju učitelji, što je vrlo bitno za djecu kojoj su potrebne rutina i predvidljivost (Alston i Kilham, 2004; prema Coates, Lamb, Bartlett i Datta, 2017). Učitelji navode da dodjeljivanje pomoćnika određenom učeniku u svrhu individualne podrške dovodi do razvoja samopouzdanja učenika, veće motivacije, stvaranja dobrih radnih navika i spremnosti za dovršenje zadatka (Blatchford, Russell i Webster, 2012). S druge strane postoji zabrinutost da pomoćnici u nastavi mogu poticati ovisnost o drugima jer kao prioritet stavljaju dovršavanje zadatka umjesto da potiču učenike na samostalno razmišljanje i djelovanje (Moyles i Suschitzky, 1997). Nadalje prisustvo pomoćnika u nastavi povezano je s poboljšanjem ponašajnih i emocionalnih aspekata ponašanja, ali loše utječe na socijalno ponašanje (Osborne i Reed, 2011). Prema tome podrška pomoćnika u nastavi može imati dvojake učinke. Koji će utjecaji prevladati, ovisi o osposobljenosti pomoćnika za rad sa specifičnim učenikom.

Često pomoćnici u nastavi koji rade s učenicima s poremećajem iz spektra autizma započinju s radom bez potrebne edukacije o specifičnostima tog poremećaja (Glashan, MacKay i Grieve, 2004; prema Coates i sur., 2017). Spomenuti učenici zahtijevaju specifičnu podršku da bi dosegnuli svoj puni potencijal. Batten (2005; prema Symes i Humphrey, 2012) navodi da rad s djecom s poremećajem iz spektra autizma zahtijeva razumijevanje poteškoća $\mathrm{s}$ kojima se nose i prepoznavanje njihovih manifestacija kod svakog pojedinog učenika. Puko postojanje svjesnosti o potrebama učenika možda nije dovoljno. Primjerice pomoćnici u nastavi tako mogu podupirati njihov akademski razvoj i potrebe, ali in daily teaching activities, extracurricular activities and activities outside of classroom, all under the developed work program according to the established functional abilities and needs of each individual student, and under the instructions of teachers/educators, school's professional associates, or professional team". Learning support assistants are one of the most important mediators of inclusion of children with autism spectrum disorder, and they play an important role in their education. They provide students with the consistency that they desperately need, especially in situations where teachers are replaced, which is very important for children who need routine and predictability (Alston and Kilham, 2004; according to Coates, Lamb, Bartlett, \& Datta, 2017). Teachers state that assigning learning support assistant to a certain student in order to support him individually leads to an increase in the student's self-confidence, higher motivation, creating good working habits, and readiness to complete the task (Blatchford, Russell and Webster, 2012). On the other hand, there are concerns that learning support assistants may encourage dependence on others because they prioritise task completion rather than encourage students to think and act independently (Moyles and Suschitzky, 1997). Furthermore, the presence of learning support assistants is associated with improved behavioural and emotional aspects of behaviour, but it has a negative impact on social behaviour (Osborne and Reed, 2011). Therefore, the support of a learning support assistant can have twofold effects. Which influences will prevail depends on the assistant's ability to work with a specific student.

It is often the case that learning support assistants who work with students with an autism spectrum disorder begin work without the necessary education about the specifics of the disorder (Glashan, MacKay $\&$ Grieve, 2004; according to Coates et al., 2017). Such students require specific support to reach their full potential. Batten (2005; according to Symes and Humphrey, 2012) states that working with children with autism spectrum disorder requires understanding the difficulties they face and recognising the manifestations of those difficulties in each individual student. The mere existence of an awareness of students' needs may not be enough. For example, learning support assistants can thus support their academic development and needs, but at the expense of their social needs. Therefore, involving learning 
nauštrb socijalnih potreba. Stoga je uključivanje pomoćnika u nastavi bez edukacije ili prethodnog iskustva u rad s njima neprikladno (Symes i Humphrey, 2011). Štoviše, neka su istraživanja pokazala da, ukoliko ne postoji adekvatna edukacija pomoćnika u nastavi, oni mogu predstavljati barijeru između učenika s poteškoćom i vršnjaka, pa tako zapravo potaknuti anti-inkluziju (Ainscow, 2000). Uzevši u obzir navedeno, zabrinjavajuća je činjenica što neka istraživanja pokazuju da trećina svih učitelja i pomoćnika navodi da nisu prošli edukaciju o posebnim obrazovnim potrebama učenika s kojim rade (Webster i Blatchford, 2015).

Neovisno o edukaciji koju su prošli, pomoćnici u nastavi mogu posjedovati određena znanja o radu s djecom s poremećajem iz spektra autizma te su ga samim time sposobni i procijeniti. Procjena vlastitog znanja zahtijeva razvijenu svijest o istom čime se bave istraživanja iz područja metakognicije. Metakognicija u svojoj suštini podrazumijeva mišljenje o vlastitim kognitivnim procesima (Biggs i Moore, 1993). Važna istraživanja s područja metakognicije otkrila su da znanje o vlastitom znanju igra važnu ulogu u širokom rasponu odrađenih zadataka uključujući prepoznavanje, percepciju i rješavanje problema (Metcalfe, 1986). Empirijski nalazi sugeriraju da često postoji razlika između stvarnog znanja i samoprocjene tog znanja. Stvarno znanje i samoprocjene tog znanja mogu se podudarati u samom početku stjecanja znanja, u kojem se potpuna odsutnost znanja smatra očitom. Stvarno i percipirano znanje mogu se podudarati i nakon što je puno znanja stečeno i integrirano, a pojedinac je svjestan opsežnog procesa učenja kroz koji je prošao kako bi stekao visoku razinu stručnosti. Međutim kada se usvoje neke osnovne informacije, ali dokazi o adekvatnosti znanja nisu ni lako dostupni ni uvjerljivi, odstupanja između stvarnog i percipiranog znanja mogu biti relativno velika (Park, Gardner i Thurkal, 1988). Upravo je iz navedenih razloga izuzetno važno na vrijeme i uspješno detektirati moguće postojanje jaza između samoprocijenjenog i stvarnog znanja s obzirom na to da navedeni jaz u slučaju rada s učenicima s teškoćama $u$ razvoju na koncu može polučiti negativne rezultate u obrazovanju ovih učenika. support assistants without training or previous experience in working with them is inappropriate (Symes and Humphrey, 2011). Moreover, some research has shown that if there is no adequate training of learning support assistants, they can represent a barrier between students with disabilities and their peers, actually encouraging anti-inclusion (Ainscow, 2000). Given the above, it is a worrying fact that some research shows that a third of all teachers and assistants state that they have not received special training about the special educational needs of the students they work with (Webster and Blatchford, 2015).

Regardless of the training that the learning support assistants have received, they may possess certain knowledge about working with children with autism spectrum disorder and thus may be able to assess that knowledge. Assessing one's own knowledge requires a developed awareness of it, with which research in the field of metacognition deals. Metacognition essentially denotes thinking about one's own cognitive processes (Biggs and Moore, 1993). Important research in the field of metacognition has found that knowledge of one's own knowledge plays an important role in a wide range of tasks performed, including recognition, perception, and problem solving (Metcalfe, 1986). Empirical results suggest that there is often a difference between actual knowledge and self-perception of that knowledge. Actual knowledge and self-perception of that knowledge may coincide at the very beginning of gaining knowledge, in which the complete absence of knowledge is considered obvious. Real and perceived knowledge can be matched even after a lot of knowledge has been acquired and integrated, and the individual is aware of the extensive learning process he or she has gone through in order to gain a high level of expertise. However, when some minimal information is acquired, and evidence of knowledge adequacy is not readily available or convincing, the discrepancies between actual and perceived knowledge can be relatively large (Park, Gardner \& Thurkal, 1988). It is exactly for these reasons that it is extremely important to detect, successfully and in a timely manner, the possible existence of a gap between self-perceived and actual knowledge, given that this gap in the case of working with students with disabilities can ultimately yield negative results in the education of those students. 


\section{CILJ, PROBLEMI I HIPOTEZE ISTRAŽIVANJA}

Cilj ovog istraživanja bio je ustanoviti razinu samoprocijenjenog znanja o radu s učenicima $\mathrm{s}$ autizmom i o inkluziji među pomoćnicima u nastavi. Također u radu smo pokušali povezati određene sociodemografske podatke sudionika istraživanja s njihovom samoprocjenom znanja. Usto cilj je istraživanja bio i ustanoviti koji od sociodemografskih pokazatelja pridonose samoprocjeni znanja o radu s učenicima s autizmom, ali i inkluziji općenito.

Iz navedenog cilja proizašli su sljedeći problemi istraživanja:

1. Ispitati povezanost nekih sociodemografskih pokazatelja sa samoprocijenjenim znanjem o inkluziji te samoprocijenjenim znanjem o radu s učenicima s autizmom;

2. Ispitati razlike u specifičnim znanjima o radu s učenicima s autizmom s obzirom na neke sociodemografske pokazatelje;

3. Ispitati doprinos samoprocijenjenog znanja o inkluziji ukupnoj samoprocjeni znanja o radu $\mathrm{s}$ učenicima s autizmom.

S obzirom na navedene probleme istraživanja, formulirane su sljedeće hipoteze:

H1a: Ne postoji statistički značajna povezanost između dobi, spola, početnog motiva za rad, profila završenog obrazovanja i razine završenog formalnog obrazovanja sa samoprocjenom znanja o radu s učenicima s autizmom te samoprocjenom znanja o inkluziji;

H1b:Postoji statistički značajna povezanost završene edukacije za pomoćnike u nastavi te iskustva rada s učenicima s autizmom i samoprocjene znanja o radu s učenicima s autizmom i samoprocjeni znanja o inkluziji;

H2: Postoje statistički značajne razlike u samoprocjeni specifičnih znanja o radu s učenicima s autizmom s obzirom na neke sociodemografske karakteristike sudionika;

H3: Samoprocijenjeno znanje o inkluziji statistički značajno pridonosi samoprocijenjenom znanju o radu s učenicima s autizmom.

\section{AIM, PROBLEMS AND HYPOTHESIS OF THIS RESEARCH}

The aim of this research was to establish the level of self-perceived knowledge about working with students with autism and inclusion among learning support assistants. In this paper we also tried to connect certain socio-demographic data of respondents in the research with their self-perceived knowledge. In addition, the aim of the research was to establish which of the socio-demographic indicators contribute to selfperceived knowledge about working with students with autism, but also to inclusion in general.

The following research problems arose from the stated aim:

1. Examination of the connection of some socio-demographic indicators with self-perceived knowledge about inclusion and self-perceived knowledge about working with students with autism;

2. Examination of differences in specific knowledge about working with students with autism with respect to some socio-demographic indicators;

3. Examination of the contribution of self-perceived knowledge on inclusion to overall self-perceived knowledge about working with students with autism.

Examination of the contribution of self-perceived knowledge of inclusion to overall self-perceived knowledge of working with students with autism.

H1a: There is no statistically significant correlation of age, gender, initial motivation for work, profile of completed education or level of completed formal education with self-perceived knowledge about working with students with autism or with self-perceived knowledge on inclusion;

H1b: There is a statistically significant correlation between completed training for learning support assistants and the experience of working with students with autism and self-perceived knowledge about working with students with autism and self-perceived knowledge on inclusion;

$\mathrm{H} 2$ : There are statistically significant differences in self-perceived specific knowledge about working with students with autism with respect to some socio-demographic characteristics of respondents; 


\section{METODE RADA}

Za potrebe ovog istraživanja sastavljen je upitnik Samoprocjene znanja o inkluziji i autizmu (SZIA) koji se sastoji od 2 subskale. Prva subskala nazvana je Samoprocjena specifičnih znanja o autizmu (dalje u tekstu SSZA) koja hipotetskim tvrdnjama mjeri samoprocijenjeno znanje o radu s učenicima s autizmom (primjer čestice: "Stekao/la sam dovoljno znanja da mogu ili bih mogao/la stvoriti poticajno okruženje za učenika s autizmom"), dok je druga subskala nazvana Samoprocjena općih znanja o inkluziji (dalje u tekstu SOZI) te ona hipotetskim tvrdnjama mjeri samoprocijenjeno znanje pomoćnika u nastavi o inkluziji općenito (primjer čestice: "Na edukaciji/fakultetu sam stekao/la dovoljno znanja o ishodima učenja pojedinog nastavnog predmeta").

Također za potrebe istraživanja sastavljen je i Sociodemografski upitnik kojim su prikupljeni podaci o sudionicima istraživanja, a koji se odnose na: dob, spol, početni motiv za rad u ulozi pomoćnika u nastavi, razinu završenog formalnog obrazovanja, godine rada u ulozi pomoćnika u nastavi, završenu edukaciju za pomoćnika u nastavi, profil završenog obrazovanja, vrstu ugovora na koji su zaposleni, županiju rada te iskustvo u radu s učenicima s autizmom.

\section{Sudionici i postupak istraživanja}

Istraživanje je provedeno u prosincu 2019. i siječnju 2020. godine (šk. god. 2019/2020.), na uzorku od 425 pomoćnika u nastavi, od čega $89,2 \%(\mathrm{~N}=379)$ ženskog, a $10,8 \%(\mathrm{~N}=46)$ muškog spola. Na službene e-mail adrese svih osnovnih škola u RH upućen je online obrazac anketnog upitnika sa zamolbom da iste proslijede pomoćnicima u nastavi koji u tim školama rade. Prosječna dob sudionika bila je 34 godine. Nadalje istraživanjem su obuhvaćeni sudionici iz svih hrvatskih županija, pri čemu ih je najviše iz Grada Zagreba $(\mathrm{N}=68$; 16\%), a najmanje iz Šibensko-kninske županije $(\mathrm{N}=6 ; 1,4 \%)$. Prema podacima dobivenim od Ministarstva znanosti i obrazovanja ukupan uzorak od 425 sudionika čini 9,4\% ukupnog broja pomoćnika u nastavi u osnovnim i srednjim školama u šk. god. 2019/2020. Potrebno je naglasiti da je praksa
H3: Self-perceived knowledge on inclusion was shown to contribute statistically significantly to self-perceived knowledge of working with students with autism.

\section{METHODS}

The questionnaire Self-Perceived Knowledge on Inclusion and Autism (SZIA), which consists of two subscales, was designed for the purposes of this research. The first subscale is called Self-Perceived Specific Knowledge on Autism (hereinafter: SSZA), which measures self-perceived knowledge of working with students with autism in terms of hypothetical claims (particular example: "I have gained enough knowledge to be able or would be able to create a stimulating environment for a student with autism"), while the second subscale is called Self-Perceived General Knowledge on Inclusion (hereinafter: SOZI), and it measures the self-perceived knowledge of a learning support assistant about inclusion in general in terms of hypothetical statements (particular example: "At training/university I gained enough knowledge about the learning outcomes of a particular subject").

Also, a socio-demographic questionnaire was compiled, which collected data on research respondents for the needs of the research. The data related to age, gender, initial motive for working as a learning support assistant, level of completed formal education, years of work as a learning support assistant, completed training for learning support assistants, profile of completed education, type of employment contract, county of work and experience in working with students with autism.

\section{Respondents and the research process}

The research was carried out during December 2019 and January 2020 (school year 2019/2020) on a sample of 425 learning support assistants, of which $89.2 \%(n=379)$ were female and $10.8 \%(n=46)$ were male. An online questionnaire was sent to the official e-mail addresses of all primary schools in the Republic of Croatia with a request to forward them to learning support assistants who work in those schools. The respondent's average age was 34 years. Furthermore, the survey included respondents from all Croatian counties, with most of them coming from the City of Zagreb $(\mathrm{n}=68 ; 16 \%)$ and the fewest from Sibenik-Knin County $(n=6 ; 1.4 \%)$. 
zapošljavanja i praćenja kvalitete rada pomoćnika u nastavi neujednačena i ovisi o osnivaču škole stoga ne postoji jedinstvena baza istih iz koje bi se mogli vidjeti podaci o obrazovnom statusu, edukacijama i ostalim sociodemografskim karakteristikama na nacionalnoj razini. Popunjavanje upitnika trajalo je oko 20 minuta i u potpunosti je bilo dobrovoljno i anonimno. Obrada podataka napravljena je u programu Statistika 13.2.

\section{REZULTATI}

U svrhu provjere opravdanosti korištenja parametrijske statistike ispitane su distribucije podataka dobivenih korištenjem prethodno navedenih upitnika. Normalitet varijabli provjeren je analizom grafičkog prikaza distribucija podataka te indeksa asimetričnosti i spljoštenosti navedenih u Tablici 2. S obzirom na to da se indeksi asimetričnosti manji od tri, a indeksi spljoštenosti manji od 10 (Kline, 1998) smatraju prihvatljivima, opravdane su pretpostavke za korištenje parametrijskih postupaka u daljnjim analizama.

Prije daljnje analize podataka pristupili smo eksploratornoj faktorskoj analizi glavnih komponenti. Bartlettov test korelacijske matrice pokazao se visokim $\left(\chi^{2}=15277,06 ; p<, 01\right)$, a KaiserMeyer-Olkinov indeks adekvatnosti uzorkovanja iznosio je ,98 te je time potvrđena pogodnost korelacijske matrice za faktorizaciju. Od 32 varijable, pet ih je isključeno iz daljnje analize zbog suviše niskog zajedničkog varijabiliteta ili neuklapanja u faktorski koncept. Guttman-Kaiserov kriterij, jednako kao i Screeplot kriterij, izlučio je dva faktora $(18,79 ; 1,37)$, a rezultati kose direct oblimin rotacije prikazani su u Tablici 1 .

Uvidom u rezultate faktorske analize može se vidjeti da prvi izlučeni faktor sadrži 23 čestice te je, s obzirom na to da se česticama unutar njega procjenjuju neka konkretna znanja vezana uz autizam i rad s djecom s ovom poteškoćom, nazvan Samoprocjena specifičnih znanja o autizmu (SSZA). Drugi izlučeni faktor ispituje samoprocjenu znanja o inkluziji i njenim elementima te sadrži četiri čestice, a nazvan je Samoprocjena općih znanja o inkluziji (SOZI). Koeficijent pouzdanosti tipa unutarnje konzistencije Cronbach Alpha za prvu subskalu (SSZA) iznosi $\alpha=, 99$, a za drugu
According to data obtained from the Ministry of Science and Education of the Republic of Croatia, the total sample of 425 respondents made up $9.4 \%$ of the total number of learning support assistants in primary and secondary schools in the school year 2019/2020.

It should be emphasised that the practice of hiring and monitoring the work quality of learning support assistants is inconsistent and depends on founder of the school, so there is no single database with data on education, educational status or any other sociodemographic characteristics at the national level.

Completing the questionnaire took about 20 minutes and was completely voluntary and anonymous. Data processing was done in the program Statistica 13.2.

\section{RESULTS}

In order to check the justification of the use of parametric statistics, the distributions of data obtained using the aforementioned questionnaires were examined. The normality of the variables was checked by analysing the graphical representation of the data distributions and the skewness index and kurtosis index listed in Table 2. Given that skewness indexes less than 3 and kurtosis indexes less than 10 are considered acceptable (Kline, 1998), the use of parametric procedures in further analyses was justified.

Prior to further data analysis, we proceeded to an exploratory factor analysis of the major components. Bartlett's test was high $(\chi 2=15277.06 ; p<.01)$, and the Kaiser-Meyer-Olkin sampling adequacy index was .98 , thus confirming the suitability of the correlation matrix for factorisation. Of the 32 variables, 5 were excluded from further analysis because common variability was too low or they did not fit into the factor concept. The Guttman-Kaiser criterion, as well as the Screeplot criterion, extracted 2 factors $(18.79 ; 1.37)$, and the results of oblique direct oblimin rotation are shown in Table 1.

Insight into the results of the factor analysis showed that the first extracted factor contained 23 particles and, given that the particles within it assess some specific knowledge related to autism and working with children with this difficulty, it was called Self-Perceived Specific Knowledge on Autism (SSZA). The second extracted factor examines the self-perceived knowledge on inclusion and its elements and contains 4 particles, and it was called the Self- 
Denis Jurković, Anita Penić Jurković, Iva Maglić: Autizam i samopercepcija znanja pomoćnika u nastavi

Tablica 1. Rezultati eksploratorne faktorske analize glavnih komponenata / Table 1. Results of exploratory factor principal component analysis

\begin{tabular}{|c|c|c|c|c|c|c|}
\hline \multirow[t]{2}{*}{ Code } & \multirow[t]{2}{*}{ Variable } & \multicolumn{2}{|c|}{$\begin{array}{l}\text { Pattern } \\
\text { matrix }\end{array}$} & \multicolumn{2}{|c|}{\begin{tabular}{|c|}
$\begin{array}{c}\text { Structure } \\
\text { matrix }\end{array}$ \\
\end{tabular}} & \multirow[t]{2}{*}{$\begin{array}{c}\text { Commu- } \\
\text { nalities }\end{array}$} \\
\hline & & 1 & 2 & 1 & 2 & \\
\hline AUT13 & $\begin{array}{l}\text { I have gained enough knowledge that I can or could create a stimulating environment } \\
\text { for a student with autism. }\end{array}$ & .929 & -.055 & .920 & .636 & .799 \\
\hline AUT19 & $\begin{array}{l}\text { I can or could perform an adequate intervention to solve crisis situations of students } \\
\text { with autism using my acquired knowledge. }\end{array}$ & .922 & -.167 & .919 & .651 & .675 \\
\hline AUT8 & $\begin{array}{l}\text { The knowledge I have helps me or could help me encourage students with autism to } \\
\text { interact with the environment. }\end{array}$ & .920 & -.057 & .910 & .602 & .781 \\
\hline AUT7 & $\begin{array}{l}\text { I contribute or could contribute to increasing the independence of students with } \\
\text { autism using my acquired knowledge. }\end{array}$ & .917 & -.023 & .903 & .608 & .814 \\
\hline \begin{tabular}{|l|} 
AUT14 \\
\end{tabular} & $\begin{array}{l}\text { I consider that I have or would have sufficient knowledge to apply work methods } \\
\text { suitable for students with autism. }\end{array}$ & .906 & .007 & .902 & .580 & .829 \\
\hline AUT24 & $\begin{array}{l}\text { I think I have enough knowledge that I can or could help a teacher work with a } \\
\text { student with autism. }\end{array}$ & .904 & -.039 & .897 & .621 & .773 \\
\hline \begin{tabular}{|l|} 
AUT18 \\
\end{tabular} & $\begin{array}{l}\text { I think that the acquired knowledge is sufficient or could be sufficient for me to plan } \\
\text { appropriate support in the implementation of activities for students with autism. }\end{array}$ & .887 & -.082 & .893 & .556 & .697 \\
\hline \begin{tabular}{|l|} 
AUT21 \\
\end{tabular} & $\begin{array}{l}\text { The acquired knowledge has helped me or could help me in properly monitoring the } \\
\text { achievements of students with autism. }\end{array}$ & .887 & .026 & .892 & .631 & .817 \\
\hline AUT6 & I think I am educated enough to work with students with autism. & .885 & -.019 & .891 & .618 & .762 \\
\hline AUT12 & $\begin{array}{l}\text { I encourage, or could encourage, the interests of students with autism using my } \\
\text { acquired knowledge. }\end{array}$ & .885 & .054 & .883 & .548 & .849 \\
\hline AUT26 & $\begin{array}{l}\text { The acquired knowledge is sufficient or could be sufficient to encourage the } \\
\text { developmental characteristics of students with autism. }\end{array}$ & .875 & -.019 & .879 & .613 & .745 \\
\hline AUT17 & $\begin{array}{l}\text { The acquired knowledge helps me or could help me in organising the activities of } \\
\text { students with autism. }\end{array}$ & .865 & .082 & .879 & .555 & .848 \\
\hline AUT9 & I have gained enough knowledge to teach social skills to students with autism. & .860 & .056 & .873 & .563 & .806 \\
\hline AUT23 & $\begin{array}{l}\text { The knowledge gained helps me or could help me understand everything a teacher } \\
\text { asks of students with autism. }\end{array}$ & .858 & -.021 & .869 & .627 & .713 \\
\hline AUT16 & $\begin{array}{l}\text { I can or could demonstrate well the task or behaviour that I want a student with } \\
\text { autism to perform using my acquired knowledge. }\end{array}$ & .856 & .013 & .865 & .576 & .749 \\
\hline AUT25 & $\begin{array}{l}\text { The knowledge I have gained has helped me or could help me understand the } \\
\text { guidelines of professional associates for working with a student with autism. }\end{array}$ & .854 & .056 & .863 & .557 & .796 \\
\hline \begin{tabular}{|l|} 
AUT11 \\
\end{tabular} & $\begin{array}{l}\text { I have enough knowledge to encourage others to socialise with or interact with a } \\
\text { student with autism. }\end{array}$ & .840 & .079 & .860 & .586 & .799 \\
\hline AUT20 & $\begin{array}{l}\text { The acquired knowledge helps me or could help me in the proper use of teaching } \\
\text { materials and aids for a student with autism. }\end{array}$ & .838 & .063 & .844 & .543 & .775 \\
\hline AUT15 & $\begin{array}{l}\text { I consider that I have or would have sufficient knowledge to follow individualised } \\
\text { educational programmes for students with autism. }\end{array}$ & .835 & .038 & .833 & .501 & .740 \\
\hline \begin{tabular}{|l|} 
AUT27 \\
\end{tabular} & $\begin{array}{l}\text { I think that I have enough knowledge to be able to properly inform the school's } \\
\text { professional service about the progress of students with autism. }\end{array}$ & .805 & .097 & .832 & .592 & .761 \\
\hline AUT22 & $\begin{array}{l}\text { I can or could provide adequate rehabilitation support to a student with autism with } \\
\text { the acquired knowledge. }\end{array}$ & .780 & .080 & .812 & .439 & .697 \\
\hline AUT1 & I am additionally educating myself with targeted content related to autism. & .698 & .057 & .772 & .630 & .542 \\
\hline AUT10 & $\begin{array}{l}\text { At training/university, I gained enough knowledge to establish communication with a } \\
\text { student with autism. }\end{array}$ & .630 & .216 & .735 & .515 & .623 \\
\hline $\mathrm{OZ2}$ & $\begin{array}{l}\text { At training/university I gained enough knowledge about the learning outcomes of a } \\
\text { particular subject. }\end{array}$ & -.068 & .889 & .574 & .846 & .715 \\
\hline OZ3 & I think I have enough knowledge about the curriculum. & .032 & .824 & .650 & .845 & .716 \\
\hline $\mathrm{OZ4}$ & $\begin{array}{l}\text { I believe that during my studies/training I learned and understood the difference } \\
\text { among segregation, integration and inclusion. }\end{array}$ & .064 & .740 & .516 & .844 & .615 \\
\hline OZ1 & I have enough knowledge about inclusive upbringing and education. & .166 & .736 & .551 & .783 & .730 \\
\hline
\end{tabular}


Hrvatska revija za rehabilitacijska istraživanja 2020, Vol 56, br. 2, str. 132-153

Tablica 2. Osnovni deskriptivni pokazatelji sociodemografskih podataka sudionika istraživanja / Table 2. Basic descriptive indicators of socio-demographic data of respondents

\begin{tabular}{|c|c|c|c|c|c|c|c|c|}
\hline Variable & Min. & Max. & $\mathbf{M}$ & $\mathbf{C}$ & D & SD & Sk. & Ku. \\
\hline Age & 19 & 69 & 34.28 & 32 & 26 & 9.040 & .708 & -.013 \\
\hline Sex & 1 & 2 & 1.89 & 2 & 2 & .311 & -2.531 & 4.426 \\
\hline Initial motive for working as a learning support assistant & 1 & 2 & 1.56 & 2 & 2 & .496 & -.262 & -1.941 \\
\hline Level of completed formal education & 2 & 6 & 3.10 & 3 & 2 & 1.271 & .807 & -.485 \\
\hline Number of years working as a learning support assistant & 1 & 10 & 2.84 & 2 & 1 & 1.812 & 1.141 & 1.221 \\
\hline I have completed training for a learning support assistant & 1 & 2 & 1.19 & 1 & 1 & .389 & 1.621 & .630 \\
\hline Profile of completed education & 1 & 5 & 1.94 & 1 & 1 & 1.185 & 1.098 & .079 \\
\hline Experience in working with students with autism & 1 & 2 & 1.48 & 1 & 1 & .500 & .080 & -2.003 \\
\hline SSZA & 23 & 92 & 65.26 & 69 & 92 & 19.495 & -.488 & -.782 \\
\hline SOZI & 4 & 16 & 11.63 & 12 & 12 & 3.328 & -.498 & -.742 \\
\hline
\end{tabular}

$\mathrm{N}=425$; Legend: Sex: 1=Male, $2=$ Female; Initial motive for working as a learning support assistant: $1=$ Lack of job opportunities in my profession, $2=$ Desire to help children with special needs; Level of completed formal education: 1=Elementary School, 2=High School, 3=Undergraduate study, 4=Graduate study, 5=Professional study, 6=Master's degree/doctorate; Number of years working as a learning support assistant: respondents entered the number of years; I have completed training for a learning support assistant: Yes $=1, \mathrm{No}=2$; Profile of completed education: $1=$ Social studies; $2=$ Humanities, $3=$ Natural science studies, 4=Technical studies, 5=Art studies; Experience in working with students with autism: $1=\mathrm{I}$ have, $2=\mathrm{I}$ do not have.

(SOZI) $\alpha=, 85$. Interfaktorska korelacija navedenih faktora iznosi $\mathrm{r}=, 96(\mathrm{p}<, 01)$, a Cronbach Alpha cjelokupne skale, koju smo nazvali Skala samoprocjena znanja o autizmu i inkluziji (SZIA), iznosi $\alpha=, 82$. S obzirom na to da je istraživački interes usmjeren $\mathrm{k}$ doprinosu pojedinih navedenih faktora, subskale definirane analizom koristiti će se kao dvije zasebne skale.

Nadalje interes je bio usmjeren $\mathrm{k}$ deskriptivnim podacima koji su prikazani u Tablici 2.

Deskriptivni podaci pokazuju da je kao početni motiv za rad u ulozi pomoćnika u nastavi češća želja za pomaganjem djeci s posebnim potrebama $(56,5 \%)$, dok je nedostatak posla u struci motiv za 43,5\% sudionika. Sudionici su najčešće završili srednju školu ( $\mathrm{N}=207 ; 48,7 \%)$, zatim diplomski studij $(\mathrm{N}=102 ; 24 \%)$, preddiplomski studij $(\mathrm{N}=56 ; 13,2 \%)$, stručni studij $(\mathrm{N}=32 ; 7,5 \%)$ te magisterij ili doktorat $(\mathrm{N}=28 ; 6,6 \%)$. Najčešće im je ovo prva godina rada u ulozi pomoćnika u nastavi $(\mathrm{N}=116 ; 27,3 \%)$, a zatim slijede druga godina $(\mathrm{N}=110 ; 25,9 \%)$, treća godina $(\mathrm{N}=72$; $16,9 \%)$, četvrta godina $(\mathrm{N}=49 ; 11,5 \%)$, peta godina $(\mathrm{N}=39 ; 9,2 \%)$ te šest ili više godina $(\mathrm{N}=38$; $9,2 \%$ ). Edukaciju su prošla 346 sudionika $(81,4 \%)$. Gledajući profil završenog formalnog obrazovanja, zaključuje se da su sudionici većinom završili neki društveni smjer $(\mathrm{N}=215 ; 50,6 \%)$, zatim humanistički $(\mathrm{N}=102 ; 24 \%)$, tehnički $(\mathrm{N}=46 ; 10,8 \%)$,
Perceived General Knowledge on Inclusion (SOZI). Cronbach's Alpha was $\alpha=.99$ for the first subscale (SSZA) and $\alpha=.85$ for the second subscale (SOZI). The interfactor correlation of these factors was $r=.96$ $(\mathrm{p}<.01)$, and the Cronbach's Alpha of the whole scale, which we called the Self-Perceived Knowledge on Autism and Inclusion (SZIA), was $\alpha=.82$. Given that the present research focused on the separate contributions of these factors, the subscales defined by the analysis were used as two separate scales.

Furthermore, interest was focused on the descriptive data shown in Table 2.

Descriptive data show that as an initial motive for working as a learning support assistant, the desire to help children with special needs was more frequent $(56.5 \%)$, while lack of work in the profession was a motive for $43.5 \%$ of respondents. Respondents had completed high school most often $(n=207 ; 48.7 \%)$, followed by graduate studies ( $\mathrm{n}=102 ; 24 \%$ ), undergraduate studies $(\mathrm{n}=56 ; 13.2 \%)$, and professional studies $(n=32 ; 7.5 \%)$ and a master's degree or doctorate $(n=28$; $6.6 \%$ ). Most often this was their first year of work as a learning support assistant $(\mathrm{n}=116 ; 27.3 \%)$, followed by the second year $(n=110 ; 25.9 \%)$, the third year $(n=72$; $16.9 \%)$, fourth year $(n=49 ; 11.5 \%)$, fifth year $(n=39$; $9.2 \%)$ and 6 or more years $(n=38 ; 9.2 \%)$. A total of 346 of the respondents $(81.4 \%)$ underwent training. Regarding the profile of completed formal education, participants had mostly completed some social study 
Tablica 3. Pearsonovi koeficijenti korelacije sociodemografskih čimbenika i analiziranih subskala samoprocijenjenog znanja / Table 3. Pearson correlation coefficients of socio-demographic factors and analysed subscales of self-perceived knowledge

\begin{tabular}{|c|c|c|c|c|c|c|c|c|c|c|}
\hline Variables & $\mathbf{1}$ & $\mathbf{2}$ & $\mathbf{3}$ & $\mathbf{4}$ & $\mathbf{5}$ & $\mathbf{6}$ & $\mathbf{7}$ & $\mathbf{8}$ & $\mathbf{9}$ & $\mathbf{1 0}$ \\
\hline 1 & 1 & & & & & & & & & \\
\hline 2 & $.70^{* *}$ & 1 & & & & & & & & \\
\hline 3 & -.01 & .03 & 1 & & & & & & & \\
\hline 4 & .06 & .03 & .06 & 1 & & & & & & \\
\hline 5 & $.10^{*}$ & .04 & .09 & $.12^{*}$ & 1 & & & & & \\
\hline 6 & -.03 & .06 & $-.10^{*}$ & $-.12^{*}$ & $-.32^{* *}$ & 1 & & & & \\
\hline 7 & $.11^{* *}$ & .07 & $.20^{* *}$ & -.06 & .06 & -08 & 1 & & & \\
\hline 8 & $-.12^{*}$ & -.07 & $-.24^{* *}$ & -.01 & $-.11^{*}$ & $.11^{*}$ & $-.31^{* *}$ & 1 & & \\
\hline 9 & -.05 & -.01 & .09 & -.06 & .07 & -.04 & -.07 & .05 & 1 & \\
\hline 10 & $-.35^{* *}$ & -.09 & $-.12^{*}$ & .02 & -.09 & -.03 & $-.18^{* *}$ & $.18^{* *}$ & .08 & 1 \\
\hline
\end{tabular}

Legend: $\mathrm{N}=221 ; * * \mathrm{p}<.01, * \mathrm{p}<.05$; Variables: 1 - SSZA, 2 - SOZI, 3 - Age, 4 - Sex, 5 - Initial motive for working as a learning support assistant, 6 - Level of completed formal education, 7 - Number of years working as a learning support assistant, 8 - I have completed training for a learning support assistant, 9 - Profile of completed education, 10 - Experience in working with students with autism.

prirodoslovni $(\mathrm{N}=45 ; 10,6 \%)$ te umjetnički $(\mathrm{N}=$ $17 ; 4 \%$ ). Na koncu, 52\% (221 sudionik) ima iskustvo rada s učenicima s autizmom dok ostatak nema takva iskustva.

U svrhu provjere pretpostavki proizašlih iz prvog problema provedena je korelacijska analiza čiji su rezultati prikazani u Tablici 3.

Iz navedene tablice vidljive su statistički značajne povezanosti među analiziranim varijablama. U ovom ćemo pregledu prikazati korelacije samo onih varijabli koje su nam od znanstvenog interesa u ovom radu, a ostale je koeficijente povezanosti moguće pročitati u Tablici 3. Slijedom rečenoga, a ujedno i ono što nas je i najviše zanimalo u ovom radu, može se vidjeti da postoji statistički značajna pozitivna povezanost između faktora SSZA i SOZI $(\mathrm{r}=, 70 ; p<, 01)$ : početni motiv za rad u ulozi pomoćnika u nastavi $(\mathrm{r}=, 10 ; p<, 05) \mathrm{i}$ godine rada u ulozi pomoćnika u nastavi $(\mathrm{r}=, 11$; $p<, 01)$. S navedenom su varijablom statistički značajno negativno povezane varijable Prošao/la sam edukaciju za pomoćnika u nastavi $(\mathrm{r}=-, 12 ; p$ $<, 05)$ te iskustvo u radu s učenicima s autizmom $(\mathrm{r}=-, 35 ; p<, 01)$. Rezultati upućuju na djelomičnu potvrdu hipoteza 1 a i $1 \mathrm{~b}$. S faktorom SSZA statistički značajno povezane su varijable početni motiv za rad u ulozi pomoćnika u nastavi, edukacija za pomoćnika u nastavi i iskustvo u radu $s$ učenicima s autizmom, a nijedna od navedenih $(\mathrm{n}=215 ; 50.6 \%)$, then humanities $(\mathrm{n}=102 ; 24 \%)$, technical study $(n=46 ; 10.8 \%)$, science study $(n=45 ; 10.6 \%)$ and artistic study $(n=17 ; 4 \%)$. Finally, 52\% (221 participants) had experience working with students with autism, while the rest had no such experience.

In order to verify the assumptions arising from the first problem, a correlation analysis was performed, the results of which are shown in Table 3.

The above table shows statistically significant correlations among the analysed variables. Here we show correlations of only those variables that were of scientific interest to us in this paper, and other correlation coefficients can be read in Table 3. Given the above, and at the same time what interested us the most in this paper, it can be seen that there was a statistically significant positive correlation between the factors $S S Z A$ and $S O Z I(\mathrm{r}=.70$; $p<.01)$, the Initial motive for working as a learning support assistant $(\mathrm{r}=.10 ; \mathrm{p}<.05)$ and Number of years working as a learning support assistant $(\mathrm{r}=.11 ; \mathrm{p}<.01)$. The variables I have completed training for a learning support assistant $(\mathrm{r}=-.12$; $p<.05)$ and Experience in working with students with autism $(\mathrm{r}=-.35 ; p<.01)$ were statistically negatively correlated with the factors $S S Z A$ and $S O Z I$.

The results suggest a partial confirmation of Hypothesis $1 \mathrm{a}$ and $1 \mathrm{~b}$. The variables Initial motive for working as a learning support assistant, Completed training for a learning support assistant and Experience 
Tablica 4. T-test analiza varijabli sa statistički značajnom korelacijom s faktorom SSZA / Table 4. T-test analysis of variables showing a statistically significant correlation with the factor SSZA

\begin{tabular}{|c|c|c|c|c|c|c|c|c|c|}
\hline \multirow[t]{3}{*}{ Variable } & \multicolumn{5}{|c|}{ SSZA } & & \multirow[t]{3}{*}{$t(423)$} & \multirow[t]{3}{*}{$\mathbf{p}$} & \multirow[t]{3}{*}{ d } \\
\hline & \multicolumn{2}{|c|}{ M } & \multicolumn{2}{|c|}{ SD } & \multicolumn{2}{|c|}{ n } & & & \\
\hline & Yes & No & Yes & No & Yes & No & & & \\
\hline Experience in working & 71.75 & 58.23 & 17.34 & 19.29 & 221 & 204 & $7.575 *$ & .00 & .74 \\
\hline Completed education & 66.41 & 60.20 & 18.94 & 21.17 & 346 & 79 & $2.573 * *$ & .02 & .31 \\
\hline Initial motive for working & 63.10 & 66.93 & 19.38 & 19.46 & 240 & 185 & $-2.011 * *$ & .05 & .20 \\
\hline
\end{tabular}

$\mathrm{N}=425,{ }^{*} \mathrm{p}<.01, * * \mathrm{p}<.05$, Initial motive: $\mathrm{YES}-$ desire to help, $\mathrm{NO}$ - lack of job opportunities in profession

Tablica 5. Jednofaktorska analiza varijance (ANOVA) čimbenika godine rada kao pomoćnik u nastavi s faktorom SSZA / Table 5. Single-factor analysis of variance (ANOVA) of the factor Number of years working as a learning support assistant with the factor SSZA

\begin{tabular}{|c|c|c|c|c|c|}
\hline \multirow[t]{2}{*}{ Number of years working: } & \multicolumn{5}{|c|}{ SSZA } \\
\hline & $\mathbf{n}$ & $\mathbf{M}$ & SD & $F(2,422)$ & $\mathbf{p}$ \\
\hline $1-2$ years & 226 & 63.73 & 19.921 & \multirow[t]{3}{*}{1.602} & \multirow[t]{3}{*}{.203} \\
\hline $3-5$ years & 160 & 66.68 & 18.936 & & \\
\hline 6 and more years & 39 & 65.26 & 19.495 & & \\
\hline
\end{tabular}

$\mathrm{N}=425$

varijabli nije statistički značajno povezana s faktorom SOZI.

U svrhu provjere drugog problema provedena je t-test analiza prikazana u Tablici 4. te analiza varijance (ANOVA) prikazana u Tablici 5.

T-test analiza potvrdila je postojanje statistički značajne razlike $\mathrm{u}$ faktoru SSZA s obzirom na početni motiv za rad $(\mathrm{t}=7,757 ; \mathrm{p}<, 05)$, završenu edukaciju za pomoćnika u nastavi $(\mathrm{t}=2,573 ; \mathrm{p}<$ ,05) te iskustvo rada s učenicima s autizmom $(\mathrm{t}=$ $-2,011 ; \mathrm{p}<, 01)$. Usto naknadnim računanjem približne veličine učinka ustvrdili smo da je između faktora SSZA i početnog motiva $d=, 20$, između faktora SSZA i Edukacija za pomoćnika u nastavi $d=, 31$ te faktora SSZA i iskustva rada s učenicima $s$ autizmom $d=, 74$. Slijedeći Cohenov (1988) kriterij o jačini utjecaja, zaključujemo da prve dvije analizirane varijable imaju malen utjecaj, dok varijabla iskustva rada s učenicima s autizmom ima srednji utjecaj.

Prije provedbe ovog testa sudionici su grupirani prema godinama rada kao pomoćnici u nastavi i to tako da su u prvu grupu ulazili svi sudionici kojima je šk. god. 2019/2020. prva ili druga godina rada te su oni smatrani početnicima u ovom poslu. Druga kategorija bili su sudionici kojima je navedena školska godina 3,4 . ili 5 . godina rada te su oni in working with students with autism were significantly associated with the SSZA factor, but none of these was significantly associated with the SOZI factor.

The t-test analysis shown in Table 4 and the analysis of variance (ANOVA) shown in Table 5 were performed in order to test the second problem.

T-test analysis confirmed the existence of a statistically significant difference in the SSZA factor with regard to the Initial motive for working $(\mathrm{t}=7.757 ; \mathrm{p}<.05)$, Completed training for a learning support assistant $(\mathrm{t}=2.573 ; \mathrm{p}<.05)$ and Experience in working with students with autism $(\mathrm{t}=-2.011$; $\mathrm{p}<.01$ ). In addition, by subsequent calculation of the approximate size of the effect, we found that between the factor SSZA and Initial motive, $\mathrm{d}=.20$; between the factor SSZA and Completed training for a learning support assistant, $\mathrm{d}=.31$; and between the factor SSZA and Experience working with students with autism, $\mathrm{d}=.74$. Based on Cohen's (1988) criterion on the strength of the influence, we conclude that the first two analysed variables had a small impact, while the variable Experience of working with students with autism had a medium impact.

Prior to the implementation of this test, the respondents were grouped according to their years of work as learning support assistants, so that the first group included all respondents who in school year 
Tablica 6. Hijerarhijska regresijska analiza faktora iskustvo rada s učenicima s autizmom, početni motiv za rad u ulozi pomoćnika u nastavi, godine rada u ulozi pomoćnika u nastavi, pohađanje edukacije za pomoćnika u nastavi te općih znanja o inkluziji s kriterijskom varijablom samoprocjena specifičnih znanja o autizmu / Table 6. Hierarchical regression analysis of the factors Experience with working with students with autism, Initial motive for working as a learning support assistant, Number of years working as a learning support assistant, Completed training for a learning support assistant, and General knowledge on inclusion with the criterion variable SelfPerceived Specific Knowledge on Autism

\begin{tabular}{|c|c|c|c|c|c|c|}
\hline \multicolumn{7}{|c|}{ Criteria: SSZA } \\
\hline & Predictor & $\boldsymbol{\beta}$ & $\mathbf{R}$ & $\mathbf{R 2}$ & adjusted R2 & $\mathbf{F}$ \\
\hline \multicolumn{2}{|l|}{ 1st step } & & .359 & .129 & .121 & $15.551 * *$ \\
\hline & Experience in working with autism & $-.327 * *$ & & & & \\
\hline & Initial motive for working & .062 & & & & \\
\hline & Number of years working & .34 & & & & \\
\hline & Completed training & -.048 & & & & \\
\hline \multicolumn{2}{|l|}{ 2nd step } & & .755 & .570 & .565 & $110.959 * *$ \\
\hline & Experience in working with autism & $.086^{* *}$ & & & & \\
\hline & Initial motive for working & .041 & & & & \\
\hline & Number of years working & .005 & & & & \\
\hline & Completed training & -.023 & & & & \\
\hline & SOZI & $.668 * *$ & & & & \\
\hline
\end{tabular}

$\mathrm{N}=425 ; * * \mathrm{p}<.01$

smatrani radnicima sa stečenim temeljnim iskustvom rada i na koncu treća kategorija onih kojima je navedena školska godina 6 . ili viša godina rada smatrani su iskusnim radnicima. ANOVA (Tablica 5) u našem slučaju nije pokazala statistički značajne razlike u faktoru SSZA s obzirom na godine rada u ulozi pomoćnika. Rezultati provedenih analiza upućuju na djelomičnu potvrdu druge hipoteze.

U svrhu provjere doprinosa iskustva rada s učenicima s autizmom, početnog motiva za rad u ulozi pomoćnika u nastavi, godina rada u ulozi pomoćnika u nastavi, pohađanja edukacije za pomoćnika u nastavi te općih znanja o inkluziji u predviđanju samoprocijenjenog znanja o autizmu, provedena je hijerarhijska regresijska analiza čiji su rezultati prikazani u Tablici 6.

Hijerarhijska regresijska analiza (Tablica 6.) pokazala je da skup prediktora u prvom koraku značajno pridonosi objašnjenju $12,1 \%$ varijance kriterija $(\mathrm{F}=15,551 ; p<, 01)$ te da samo prediktor iskustvo u radu s učenicima s autizmom statistički značajno pridonosi tom objašnjenju $(\beta=-, 327 ; p$ $<, 01)$. Nadalje u drugom smo koraku dodali prediktor SOZI te je time objašnjeno dodatnih 44,1\% varijance kriterija, odnosno svim je prediktorima statistički značajno objašnjeno $56,5 \%(F=110,959$; $p<, 01)$ ukupne varijance kriterija. $\mathrm{U}$ drugom su se
2019/2020 had been working for one or two years, and they were considered as beginners in this job. The second category were respondents who in the stated school year were in the $3^{\text {rd }}, 4^{\text {th }}$ or $5^{\text {th }}$ year of work and they were considered workers with acquired basic work experience. The third category were those who in the stated school year were in the $6^{\text {th }}$ or higher year of work, and they were considered as experienced workers. ANOVA (Table 5) in our case did not show statistically significant differences in the $S S Z A$ factor with respect to years of work as an assistant. The results of the conducted analyses indicate a partial confirmation of the second hypothesis.

In order to verify the contribution of Experience working with students with autism, Initial motive to work as a learning support assistant, Number of years working as a learning support assistant, Completed training for learning support assistants and General knowledge about inclusion to predicting self-perceived knowledge about autism, a hierarchical regression analysis was performed. The results are shown in Table 6.

Hierarchical regression analysis (Table 6) showed that the set of predictors in the first step significantly contributed to the explanation of $12.1 \%$ of the variance in the criteria $(\mathrm{F}=15.551$; $p<.01)$, and that only the predictor Experience in 
koraku dva prediktora pokazala statistički značajnima: iskustvo rada s djecom s autizmom $(\beta=, 086$; $p<, 01)$ te faktor SOZI $(\beta=, 668 ; p<, 01)$. Prema navedenim rezultatima treća je hipoteza potvrđena.

\section{RASPRAVA}

Broj djece s teškoćama iz spektra autizma u stalnom je porastu. Njihova zastupljenost u redovnim školama sve je veća, a realno je očekivati da će i dalje nastaviti rasti. Upravo je zato bitno da su svi sudionici odgojno-obrazovnog procesa, a posebice oni koji izravno rade s njima, upoznati s karakteristikama koje imaju djeca s autizmom, ali i da razumiju njihove potrebe. Rezultati istraživanja o znanju o autizmu među različitim skupinama utvrdila su prisutnost brojnih zabluda. Primjerice Helps, Newsom-Davis i Callias (1999; prema Rakap, Balikci i Parlak-Rakap, 2016) ispitivali su razinu znanja i razumijevanja autizma među učiteljima u redovnim razredima, učiteljima u posebnim razrednim odjeljenjima (bez djece $\mathrm{s}$ autizmom) i pomoćnog osoblja u Engleskoj uspoređujući ih s odgovorima stručnjaka u području autizma. Istraživači su otkrili da se pogledi učitelja na autizam znatno razlikuju od pogleda stručnjaka u svim područjima. Primjerice učitelji su smatrali da autistični učenici nemaju ozbiljnih kognitivnih poteškoća ili teškoća $s$ učenjem te da je autizam više emocionalni nego razvojni poremećaj. Kako bi mogli adekvatno pristupiti učeniku kojem nastoje pružiti podršku, uz učitelje, navedeno je znanje najpotrebnije upravo pomoćnicima u nastavi. Iako se ono pokušava razviti kroz edukacije koje većina pomoćnika prolazi prije početka rada, one često ne daju zadovoljavajuće rezultate. No uz edukacije i neki osobni faktori imaju važnu ulogu u stjecanju i zadržavanju znanja. Jedan je od njih i samopercepcija vlastitog znanja koja je često u neskladu sa stvarnim znanjem (Ziegler i Montplaisir, 2014; Cavers i Ling, 2016; Versteeg, Wijnen-Meijer i Steendijk, 2018; prema Versteeg i Steendijk, 2019), a bitno utječe na percepciju, motivaciju, rješavanje problema i druge varijable važne za učenje (Park i sur., 1988). Uzevši u obzir važnost samopercepcije znanja o autizmu i inkluziji pomoćnika u nastavi u olakšavanju inkluzije i svakodnevnog funkcioniranja djece s autizmom u odgojno-obrazovnom sustavu, autori su nastojali utvrditi kako pomoćnici working with students with autism contributed statistically significantly to that explanation $(\beta=-.327$; $p<.01)$. Furthermore, in the second step we added the predictor $S O Z I$ and thus explained an additional $44.1 \%$ of the variance of the criteria, i.e. all predictors statistically significantly explained $56.5 \%$ of the total variance of the criteria $(\mathrm{F}=110.959$; $p<.01)$. In the second step, two predictors proved to be statistically significant: Experience in working with children with autism $(\beta=.086 ; p<.01)$ and SOZI factor $(\beta=.668 ; p<.01)$. The third hypothesis was confirmed according to the results above.

\section{DISCUSSION}

The number of children with autism spectrum disabilities is on the rise. Their frequency in regular schools is increasing, and it is realistic to expect that they will continue to grow. That is why it is important that all participants in the educational process, and especially those who work directly with children with autism, are familiar with their characteristics and also understand their needs. The results of research on knowledge about autism among different groups have identified the presence of a number of misconceptions. For example, Helps, Newsom-Davis, and Callias (1999; according to Rakap, Balikci, and Parlak-Rakap, 2016) examined the level of knowledge and understanding of autism among regular class teachers, teachers in special classrooms (excluding children with autism), and support staff in England, comparing them with the responses from experts in the field of autism. Researchers have found that teachers' views on autism differ significantly from those of experts in all areas. For example, teachers felt that autistic students do not have serious cognitive or learning difficulties and that autism is more an emotional than a developmental disorder. In order to be able to adequately approach the student to whom they are trying to provide support, learning support assistants most need this knowledge, in addition to teachers. Although the training that most assistants go through before starting work is designed to transmit this knowledge, the results are often not satisfactory. Even with training, some personal factors play a major role in acquiring and retaining knowledge. One of them is the self-perception of one's own knowledge, which is often inconsistent with real knowledge (Ziegler and Montplaisir, 2014; Cavers and Ling, 
u nastavi procjenjuju vlastito znanje te kako na to utječu određene sociodemografske karakteristike. U tu svrhu konstruiran je upitnik čijom su analizom izlučena dva faktora: Samoprocjena specifičnih znanja o autizmu (SSZA) i Samoprocjena općih znanja o inkluziji (SOZI). Za mjerenje percepcije vlastitog znanja korištena je tradicionalna skala Likertovog tipa koja se najčešće koristi u istraživanjima u prosvjeti s obzirom na to da je pokazano da predstavlja bolje mjerilo samopercipiranog znanja od nekih drugih metoda (Versteeg i Steendijk, 2019).

Prvi problem na kojeg se nastojalo odgovoriti odnosio se na utvrđivanje povezanosti nekih sociodemografskih karakteristika sa samoprocijenjenim znanjem o inkluziji te samoprocijenjenim specifičnim znanjem o autizmu. S obzirom na priličnu heterogenost sudionika istraživanja u pogledu dobi, spola i varijabli vezanih za njihovo obrazovanje (vidljivo iz Tablice 1), očekivalo se da neće biti značajno povezane s navedenim skalama. Prema očekivanjima, navedene karakteristike nisu bile značajno povezane sa skalama samoprocjene znanja o autizmu i samoprocjene znanja o inkluziji. Međutim početni motiv za obavljanje posla pomoćnika u nastavi pokazao se značajno pozitivno povezanim sa samoprocijenjenim znanjem o autizmu. Prema tome svoje su znanje većim procjenjivali sudionici čiji je početni motiv bio intrinzičan, odnosno oni koje su posao počeli obavljati zbog unutrašnje želje za pomaganjem učenicima s teškoćama u razvoju, dok su pomoćnici koji su taj posao odabrali iz nužde, odnosno nedostatka posla u svojoj struci, svoje znanje procjenjivali manjim. Takav nalaz ne iznenađuje uzevši u obzir da su osobe koje su posao počele obavljati iz unutrašnjih, a ne iz neke vanjske potrebe, ujedno i motiviraniji više naučiti o teškoći i potrebama učenika s kojim rade. Upravo da sačuvaju sliku o sebi kao intrinzično motiviranih, mogu biti motiviraniji svoje znanje procijeniti kao veće, bez obzira na to postoji li sklad percipiranog i stvarnog znanja. Nadalje pretpostavljalo se da će završena edukacija za pomoćnika u nastavi i iskustvo rada s učenicima s autizmom biti značajno povezani sa skalama samoprocijenjenog znanja o autizmu i samoprocijenjenog znanja o inkluziji zbog uloženog truda u posao. Pretpostavka je djelomično potvrđena jer
2016; Versteeg, Wijnen-Meijer and Steendijk, 2018; according to Versteeg and Steendijk, 2019), and it significantly affects perception, motivation, problem solving, and other variables important to learning (Park et al., 1988). Considering the importance of self-perceived knowledge on autism and the inclusion of learning support assistants in facilitating the inclusion and daily functioning of children with autism in the educational system, the present authors sought to determine how learning support assistants assess their own knowledge and how certain socio-demographic characteristics affect it. A questionnaire was constructed for that purpose, whose analysis extracted two factors, Self-perceived specific knowledge on autism (SSZA) and Self-perceived general knowledge on inclusion (SOZI). A traditional Likert-type scale was used to measure perception of one's own knowledge, which is most often used in research in education considering that it is shown that it is a better measurement of self-perceived knowledge than some other methods (Versteeg and Steendijk, 2019).

The first problem that was sought to be answered was to determine the connection of some socio-demographic characteristics with self-perceived knowledge on inclusion and self-perceived specific knowledge on autism. Given the considerable heterogeneity of the respondents in terms of age, gender, and variables related to their education (as seen from Table 1), it was expected that they would not be significantly associated with these scales. As expected, these characteristics were not significantly related to the self-perceived knowledge on autism and self-perceived scales on inclusion. However, the initial motive for working as a learning support assistant proved to be significantly positively related to self-perceived knowledge on autism. Therefore, the respondents whose initial motive was intrinsic, i.e. those who started doing the job due to an inner desire to help students with disabilities, assessed their own knowledge higher, while assistants who chose the job out of necessity, i.e. lack of work in their profession, assessed their own knowledge as lower. Such a finding is not surprising, considering that people who started doing work for internal reasons, and not for some external need, are also more motivated to learn more about the difficulties and needs of the students they work with. Precisely to preserve the image of themselves as intrinsically motivated, they may be more motivated to assess their 
su obje varijable bile značajno povezane samo sa samoprocijenjenim znanjem o autizmu, no ne i o inkluziji. Međutim iz dobivenih podataka proizlazi da su sudionici bez iskustva rada s učenicima s autizmom te oni koji nisu prošli edukaciju za pomoćnika u nastavi svoje znanje procjenjivali većim. Ovo je saznanje donekle začuđujuće, no pronalazi uporište $u$ istraživanjima metakognicije i tzv. iluzije o znanju. Naime različita istraživanja pokazuju da ljudi ne procjenjuju uvijek svoje znanje točno i često precjenjuju koliko znaju (Dunning, 2011; prema Atir, Rosenzweig i Dunning, 2015). Znatan broj radova koji govore o tome kako ljudi evaluiraju vlastito znanje ukazuje na to da se pri tome ne oslanjaju samo na izravno preispitivanje svog mentalnog sadržaja nego i na osjećaj o znanju (eng. feeling of knowing) koji je često slab prediktor stvarnog znanja (Nelson i Narens, 1990; Reder i Ritter, 1992; prema Atir i sur., 2015). Dodatnu potvrdu ovih rezultata pruža činjenica da do najveće neusklađenosti percipiranog i stvarnog znanja dolazi u slučajevima kada osoba usvoji minimum osnovnih informacija i iskustva u nekom području (Park i sur., 1988). Moguće je da do toga dolazi zato što ljudi u potrazi za informacijama u svojem znanju posežu za prethodno stvorenim samopercepcijama znanja kako bi donijeli zaključke o tome što bi trebali znati ili što vjerojatno znaju (Koriat, 1995; prema Atir i sur., 2015).

Nadalje kroz drugi se problem nastojalo utvrditi postojanje razlika u samoprocjeni specifičnih znanja o autizmu s obzirom na iskustvo rada s djecom s autizmom, edukaciju za pomoćnika u nastavi te početni motiv za rad. Utvrđeno je da svoje znanje o autizmu procjenjuju višim oni pomoćnici u nastavi koji imaju iskustvo rada s učenicima s autizmom, koji su prošli edukaciju za pomoćnika u nastavi te oni kojima je početni motiv za rad želja za pomaganjem djeci s posebnim potrebama. Iako dosad nisu provedena istraživanja s ovom tematikom na pomoćnicima u nastavi, moguće je povući paralele $\mathrm{s}$ istraživanjima na nekim drugim skupinama zaposlenika koji pokazuju slične rezultate. Primjerice autori Yaeda, Kundu i Nishimura (2013) istraživali su samopercipirano znanje i vještine savjetnika za zapošljavanje te utvrdili da je iskustvo rada u tom području pozitivno povezano sa samoprocijenjenim znanjem. Iskustvo rada u području koje procjenju- knowledge as greater, regardless of whether there is harmony between perceived and actual knowledge.

Furthermore, it was assumed that the completed training for learning support assistants and the experience of working with students with autism would be significantly related to the scales of self-perceived knowledge on autism and self-perceived knowledge on inclusion due to the effort put into the work. The assumption was partially confirmed, as both variables were significantly associated only with self-perceived knowledge on autism, but not on inclusion. The obtained data show that participants without experience in working with students with autism and those who did not undergo training for learning support assistants rated their knowledge higher. This finding is somewhat surprising, but it finds a foothold in research on metacognition and the so-called illusion about knowledge. Namely, various studies show that people do not always evaluate their knowledge accurately and often overestimate how much they know (Dunning, 2011; according to Atir, Rosenzweig and Dunning, 2015). A considerable number of papers on how people evaluate their own knowledge indicate that they rely not only on a direct re-examination of their mental content, but also on a feeling of knowing, which is often a weak predictor of real knowledge (Nelson and Narens, 1990; Reder and Ritter, 1992; according to Atir et al., 2015). Additional confirmation of these results is provided by the fact that the greatest mismatch between perceived and actual knowledge occurs in cases where a person acquires minimal information and experience about an area (Park et al., 1988). It is possible that this occurs because people seeking information within their knowledge reach for previously created self-perceptions of knowledge to draw conclusions about what they should know or probably know (Koriat, 1995; according to Atir et al., 2015).

Furthermore, through the second problem it was sought to determine the existence of differences in selfperceived specific knowledge on autism with regard to the experience of working with children with autism, training for learning support assistants and the initial motive for work. It was found that knowledge about autism was self-assessed as higher by those learning support assistants who had experience working with students with autism, who had been trained as learning support assistants and whose initial motive for work was the desire to help children with special needs. 
jemo može nam pružiti veći osjećaj samoučinkovitosti, a samim time i kompetencije. Neovisno o tome stječemo li kroz iskustvo stvarno znanje, samo susretanje s mnoštvom informacija u određenom području stvara svjesnost o istome te tako može utjecati na percepciju vlastitog znanja kao većeg. Pri tome je važno napomenuti da kroz analize nije utvrđena značajna razlika za samoprocjenu znanja o autizmu u odnosu na godine rada koje su sudionici proveli obavljajući posao pomoćnika u nastavi. Ovaj rezultat ne iznenađuje s obzirom na to da postoje pomoćnici koji se u svom, moguće i dugotrajnom radu nisu susretali s djecom koja su imala poteškoće iz spektra autizma. Prema tome u ovom kontekstu relevantnija varijabla od godina rada u ulozi pomoćnika u nastavi svakako je iskustvo rada s učenicima s autizmom. Osim navedenih objašnjenja potrebno je istaknuti da se osobna važnost područja koje se procjenjuje pokazala vrlo bitnom za percepciju vlastitog znanja. Naime osobna važnost nekog područja bitno utječe na procese pažnje i razumijevanja neke informacije koja je povezana s tim područjem (Greenwald i Leavitt, 1984; prema Radecki i Jaccard, 1995). Radecki i Jaccard (1995) ističu da je kognitivna disonanca mehanizam kojim se može objasniti pojava da višim procjenjujemo vlastito znanje $u$ onom području koje nam je osobno važno. Naime kada je neko područje osobi važno, spoznaja da malo zna o njemu stvara disonancu. To se posebno može pojaviti kod osoba koje su već uložile neki trud u stjecanje znanja o tom području (poput pohađanja edukacije za pomoćnika u nastavi). Prema ovakvom shvaćanju osobna važnost nekog područja utjecat će na samoprocjenu vlastitog znanja neovisno o tome koliko je stvarno znanje. Što je područje važnije i relevantnije za pojedinca to bi on mogao višim procjenjivati razinu svog znanja o tom području.

Posljednjom analizom nastojao se provjeriti doprinos nekih varijabli u objašnjavanju varijance samoprocijenjenog specifičnog znanja o autizmu. Provedena je hijerarhijska regresijska analiza u koju su uključene varijable koje su se u prijašnjim analizama pokazale značajno povezanima sa samoprocijenjenim znanjem o autizmu. Rezultati su pokazali da iskustvo rada s učenicima s autizmom te samoprocjena općih znanja o inkluziji imaju zna-
Although no research on this topic has been conducted on learning support assistants so far, it is possible to draw parallels with research on some other groups of employees that show similar results. For example, Yaeda, Kundu, and Nishimura (2013) researched the self-perceived knowledge and skills of employment counsellors and found that work experience in this area is positively associated with self-perceived knowledge. Experience working in the area that we are assessing can give us a greater sense of self-efficacy and, thus, competence. Regardless of whether we acquire real knowledge through experience, just by absorbing a lot of information in a certain area creates awareness of the same and thus can affect the perception of our own knowledge as greater. It is important to note that the analyses did not reveal a significant difference in self-perceived knowledge about autism in relation to the years of work that respondents had spent working as learning support assistants. This result is not surprising given that there are assistants who have not encountered children with autism spectrum difficulties, even after working for a while. Therefore, in this context, a more relevant variable than years of work as a learning support assistant is certainly the experience of working with students with autism. In addition to the stated explanations, it should be noted that the personal importance of the area being assessed is very important for the perception of one's own knowledge. Namely, the personal importance of an area significantly affects the processes of attention and understanding of some information related to that area (Greenwald and Leavitt, 1984; according to Radecki and Jaccard, 1995). Radecki and Jaccard (1995) point out that cognitive dissonance is a mechanism by which we can explain the phenomenon that we rate our own knowledge higher in an area that is personally important to us. Namely, when an area is important and relevant to a person, a person's understanding that he/ she knows little about it creates dissonance. This may especially be the case for people who have already made some effort to acquire knowledge about that field (such as attending training in becoming a learning support assistant). According to this understanding, the personal importance of an area will affect the self-perception of one's own knowledge, no matter how real the knowledge is. The more important and relevant an area is to an individual, the higher that person may assess the level of his or her knowledge of that area. 
čajan pozitivan doprinos percepciji vlastitog znanja o autizmu, pri čemu je doprinos znanja o inkluziji imao veći utjecaj. Znanje o inkluziji i znanje o autizmu međusobno je isprepleteno, pa je ovaj nalaz očekivan. Naime iz svega rečenog o samopercepciji znanja može se zaključiti je da će općenita znanja, čak i ako su percipirana, a ne stvarna, utjecati na doživljaj vlastitih specifičnih znanja. Iako su osnovni didaktički principi induktivnog karaktera te zahtijevaju učenje konkretnog da bi se dostigla apstraktna razinu, u ovom se slučaju mora uzeti u obzir i iskustvena dimenzija samoprocjene znanja. Među sudionicima istraživanja bila je gotovo polovica onih koji nisu imali iskustva rada s učenicima s autizmom, no prošli su edukaciju za pomoćnika u nastavi te time, barem formalno, stekli znanja o autizmu. S obzirom na vremenski ograničen period edukacije, a samim time i obujam gradiva vezanog za autizam, za očekivati je da će mnogi od njih pri samoprocjeni znanja o autizmu koristiti znanja koja su stekli o inkluziji općenito te ih, posredno, pokušati primijeniti i na ovo specifično područje. Kroz transfer znanja iz općeg u specifičnu poteškoću moguće je da će se bitnim pokazati ono što su svi sudionici stekli, bez obzira na iskustvo. U ovom je slučaju to općenito znanje o inkluziji.

Brojni pomoćnici u nastavi prolaze kratke edukacije o radu s djecom s teškoćama u razvoju te se očekuje da će nakon toga biti uspješni u svom radu. Međutim na uspješan rad pomoćnika u nastavi utječu i brojni drugi faktori. Naime, iako edukacije za pomoćnike u nastavi imaju puno prostora za poboljšanje, potrebno je obratiti pozornost i na motivaciju pomoćnika za učenjem i stjecanjem novih znanja. Naime nekad nije toliko važno što ljudi u određenom trenutku znaju nego jesu li sposobni prepoznati praznine u trenutnom znanju koje bi ih pomogle motivirati na novo učenje. Prema tome sposobnost učenja i promjene nije samo funkcija stvarnog znanja nego ovisi i o osjećajima o tom znanju (Bransford, 1979; Glenberg i sur., 1982; prema Park i sur., 1988). Niska procjena vlastitog znanja može povećati motivaciju za učenjem, dok visoka samopercepcija znanja o nekom području može dovesti do pretrage pamćenja koje je pristrano i vodi potvrdi teze (Kunda, 1990; prema Atir i sur., 2015), što može imati negativne posljedice.
The present analysis sought to examine the contribution of some variables in explaining the variance of self-perceived specific knowledge about autism. A hierarchical regression analysis was performed that included variables that had been shown in previous analyses to be significantly related to self-perceived knowledge about autism. The results showed that the experience of working with students with autism and self-perceived general knowledge about inclusion had a significant positive contribution to the perception of one's own knowledge about autism, with the contribution of knowledge about inclusion having a greater impact. Knowledge on inclusion and knowledge on autism are intertwined, so this finding is to be expected. Namely, from all that has been said about selfperceived knowledge, it is to be expected that general knowledge, even if it is perceived and not real, will affect the experience of one's own specific knowledge. Although the basic didactic principles are of an inductive nature and require learning the concrete in order to reach the abstract level, in this case the experiential dimension of self-perceived knowledge must also be taken into account. Almost half of the respondents in the research were those who had no experience working with students with autism, but they had received training for learning support assistants and thus, at least formally, they had acquired knowledge about autism. Given the limited period of training, and thus the volume of material related to autism, it is expected that many of them with self-perceived knowledge about autism would indirectly apply the knowledge gained about inclusion in general to the more specific problem of autism. Thus, all knowledge acquired by respondents may be important, regardless of experience, because they can transfer knowledge from general problems (inclusion) to specific ones (autism).

Numerous learning support assistants undergo short trainings on working with children with disabilities and are expected to be successful in their work afterwards. However, the successful work of learning support assistants is influenced by a number of other factors. Namely, even though trainings for learning support assistants have a lot of room for improvement, it is necessary to pay attention to the motivation of assistants to learn and acquire new knowledge. Sometimes what matters is not so much what people know at a given moment, but whether they are able to recognise gaps in current knowledge 
Jedna od najvažnijih posljedica u ovom kontekstu jest da tendencija preuveličavanja vlastitog znanja može obeshrabriti pojedince i odvratiti ih od edukacija u onim područjima za koja smatraju da imaju znanja i koja im mogu biti važna (Metcalfe, 2009; prema Atir i sur., 2015), odnosno odvratiti ih od postizanja stvarnog znanja.

Konačno, bitno je napomenuti i nekoliko ključnih ograničenja ovog istraživanja. Iako je broj sudionika istraživanja zadovoljavajući, u buduća bi se istraživanja moglo uključiti i edukatore u udrugama koje provode edukacije pomoćnika u nastavi. Naime, o znanjima i kompetencijama edukatora uvelike ovise i znanja i kompetencije koje će steći budući pomoćnici u nastavi. Također na taj bi se način omogućio uvid i u kvalitetu obavljanja edukacije pa bi se samim time otvorio prostor za dodatni napredak edukatora, ali i sudionika edukacije. Usto u budućim bi istraživanjima bilo korisno ispitati i stvarno znanje sudionika te na taj način utvrditi moguć (ne)razmjer između stvarnog i percipiranog znanja.

\section{ZAKLJUČAK}

Sve veća potreba za pomoćnicima u nastavi razlog je potrebe za detaljnim i dubljim promišljanjem njihove uloge u odgojno-obrazovnom sustavu. Znanja i kompetencije koja posjeduju pomoćnici svakako su neki od ključnih elemenata kroz koje je potrebno valorizirati njihov posao. U ovom smo istraživanju pokušali saznati više o samopercipiranim znanjima pomoćnika te se može zaključiti da je početni motiv za rad s učenicima s autizmom statistički značajno pozitivno, a završena edukacija za pomoćnika u nastavi, ali i samo iskustvo rada s ovim učenicima statistički značajno i negativno povezano sa samoprocjenom znanja o radu s učenicima s autizmom, no da nema bitnu ulogu u samoprocjeni znanja o inkluziji. Također, pokazali smo i da među sudionicima istraživanja postoje statistički značajne razlike pri samoprocjeni znanja o radu s učenicima s autizmom, a to se posebice odnosi na početni motiv za rad, završenu edukaciju za pomoćnika u nastavi te iskustvo rada s učenicima s autizmom, dok godine rada $u$ ulozi pomoćnika ne čine statistički značajnu razliku. Konačno, pokazalo se i da samoprocijenjeno znanje o inkluziji statistički značajno pridonosi that would help motivate them to learn again. Thus, the ability to learn and change is not only a function of actual knowledge, but it also depends on feelings about that knowledge (Bransford, 1979; Glenberg et al., 1982; according to Park et al., 1988). Low assessment of one's own knowledge can increase motivation to learn, while highly self-perceived knowledge of an area can lead to a memory search that is biased and leads to confirmation of the hypothesis (Kunda, 1990; according to Atir et al., 2015), which can have negative consequences. One of the most important consequences in this context is that the tendency to exaggerate one's own knowledge can discourage individuals and distract them from education in those areas in which they consider themselves to have knowledge and that may be important to them (Metcalfe, 2009; according to Atir et al., 2015), thereby distracting them from achieving real knowledge.

Finally, it is important to note a few key limitations of this research. Although the number of respondents is satisfactory, educators in associations that conduct teaching assistant trainings could be included in future research. The knowledge and competencies that will be acquired by future learning support assistants depend largely on the knowledge and competencies of educators. In this way, insights into the quality of education would be gained, and space would thereby open up for additional progress for both educators and participants in education. In addition, in future research, it would be useful to examine the actual knowledge of the respondents and thus determine the possible (non) relationship between actual and perceived knowledge.

\section{CONCLUSION}

The growing need for learning support assistants is the reason for the need for a detailed and deeper reflection on their role in the educational system. The knowledge and competencies possessed by assistants are certainly some of the key elements through which it is necessary to evaluate their work. In this research we tried to learn more about the self-perceived knowledge of assistants and it can be concluded that the initial motive for working with students with autism showed a statistically significantly positive relationship with self-perceived knowledge about working with those students. On the other hand, completed training for learning support assistants, but also the 
samoprocijenjenom znanju o radu s učenicima s autizmom. Na koncu valja napomenuti da ovakva istraživanja u europskim i svjetskim okvirima nisu brojna, a na području Hrvatske nismo uspjeli pronaći nijedno istraživanje koje se bavi ovom tematikom. Navedeno bi trebao biti poticaj za daljnje i dublje istraživanje kako pomoćnika u nastavi tako i njihovih znanja, samopercepcija znanja, ali i kompetencija. Istraživanja ove vrste koriste i stručnoj službi škole, i učiteljima i roditeljima učenika s autizmom, kako bi imali bolji uvid u količinu i kvalitetu znanja pomoćnika, što predstavlja jedan od ključnih elemenata za rad te utječe na ukupnu dobrobit ovih učenika.

\section{ZAHVALA}

Zahvaljujemo se svim ravnateljima, ravnateljicama i stručnim službama osnovnih škola koji su anketne upitnike proslijedili, ali i pomoćnicima u nastavi koji su upitnike ispunili.

\section{ETIČKA RAZMATRANJA}

Istraživanje je provedeno u skladu s etičkim standardima. Ispunjavanje anketnog upitnika bilo je u potpunosti dobrovoljno te se nisu ispitivali podaci koji bi na bilo koji način mogli dovesti do otkrivanja identiteta sudionika. Ispitivale su se isključivo varijable koje su uključene u istraživanje, bez traženja dodatnih osobnih podataka sudionika.

\section{SUKOB INTERESA}

Ne postoji sukob interesa u pisanju i objavi predočenog istraživanja. experience in working with students with autism are statistically significant and negatively related with selfperceived knowledge on working with those students. However, neither motive, training nor experience played an essential role in self-perceived knowledge about inclusion. We also showed statistically significant differences in self-perceived knowledge about working with students with autism among the respondents, and this was especially true for the initial motive for work, completed training for learning support assistants and experience working with students with autism, while the number of years working as an assistant did not make a statistically significant difference. Finally, self-perceived knowledge on inclusion was shown to contribute statistically significantly to selfperceived knowledge on working with students with autism. In the end, it should be noted that there are not many types of research like this in Europe and the world, and in Croatia we have not been able to find any research that deals with this topic. This should be an incentive for further and deeper research on learning support assistants and their knowledge, self-perceived knowledge, and competencies. This kind of research is useful to a school's professional service, teachers and parents of students with autism, to have better insight into the quantity and quality of knowledge of assistants, which is one of the key elements for work and affects the overall well-being of those students.

\section{ACKNOWLEDGMENTS}

We would like to thank all the principals and counsellors of primary schools who forwarded the questionnaires, as well as the learning support assistants who filled them out.

\section{ETHICAL CONSIDERATIONS}

The research was conducted in accordance with ethical standards. Completion of the survey questionnaire was entirely voluntary and no data were examined that could in any way lead to the disclosure of the identity of the participants. Only the variables included in the study were examined; additional personal data were not sought from the participants.

\section{CONFLICTS OF INTEREST}

No conflicts of interest were declared. 


\section{LITERATURA/ REFERENCES}

Ainscow, M. (2000). The Ron Gulliford Lecture: The Next Step for Special Education: Supporting the Development of Inclusive Practices. British Journal of Special Education, 27(2), 76-80. DOI: 10.1111/1467-8527.00164

Atir, S., Rosenzweig, E. i Dunning, D. (2015). When knowledge knows no bounds: Self-perceived expertise predicts claims of impossible knowledge. Psychological Science, 26(8), 1295-1303. DOI: 10.1177/0956797615588195

Biggs, J., \& Moore, P. (1993). Conceptions of learning and teaching. In: The process of learning (3rd ed). Sydney: Prentice Hall of Australia

Blatchford, P., Russell, A. i Webster, R. (2012). Reassessing the impact of teaching assistants: How research challenges practice and policy. Oxon: Routledge. DOI: 10.1111/j.1471-3802.2012.01258_2.x

Bujas-Petković, Z. (1995). Autistični poremećaj - dijagnoza i tretman. Zagreb: Školska knjiga.

Coates, M., Lamb, J., Bartlett, B. i Datta, P. (2017). Autism spectrum disorder coursework for teachers and teacheraids: An investigation of courses offered in Queensland, Australia. Australian Journal of Teacher Education, 42(11), 65-80. DOI: 10.14221/ajte.2017v42n11.5

Cohen, J. W. (1988). Statistical power analysis for the behavioral sciences (2nd edn). Hillsdale, NJ: Lawrence Erlbaum Associates.

Hayes, J.A., Baylot Casey, L., Williamson, R., Black, T. i Winsor, D. (2013). Educators' readiness to teach children with autism spectrum disorder in an inclusive classroom. The Researcher, 25(1), 67-78.

Kline, R. B. (1998). Principles and practice of structural equation modeling. New York: Guildford Press.

Lombardi, L. (2016). "I need to hear and speak and do." An exploration of the self-efficacy of teaching assistants supporting pupils with autism in mainstream primary schools. (Doktorska disertacija). University of Cardiff, Cardiff.

Ljubičić, M., Šare, S. i Markulin, M. (2014). Temeljne informacije o zdravstvenoj njezi osoba s autizmom. Sestrinski glasnik, 19(3), 231-233. DOI: 10.11608/sgnj.2014.19.048

Metcalfe, J. (1986). Feeling of knowing in memory and problem solving. Journal of Experimental Psychology Learning Memory and Cognition, 12(2), 288-294. DOI: 10.1037/0278-7393.12.2.288

Moyles, J. i Suschitzky, W. (1997). The employment and deployment of classroom support staff: Head teachers' perspectives'. Research in Education, 58, 21-34. DOI: 10.1177/003452379705800103

Osborne, L. A. i Reed, P. (2011). School factors associated with mainstream progress in secondary education for included pupils with Autism Spectrum Disorders. Research in Autism Spectrum Disorders, 5, 1253-1263. DOI: 10.1016/j.rasd.2011.01.016

Park, C. W., Gardner, M. P. i Thukral, V. K. (1988). Self-perceived knowledge: Some effects on information processing for a choice task. The American Journal of Psychology, 101(3), 401-424.

Pravilnik o pomoćnicima u nastavi i stručnim komunikacijskim posrednicima. Narodne novine, 102/2018.

Radecki, C. M. i Jaccard, J. (1995). Perceptions of knowledge, actual knowledge, and information search behavior. Journal of experimental social psychology, 31, 107-138. DOI: 10.1006/jesp.1995.1006

Rakap, S., Balikci, S. i Parlak-Rakap, A. (2016). An analysis of Turkish pre-service teachers' knowledge of autism spectrum disorder: Implications for teacher preparation programs. SAGE Open, 6(3), 1-11.

Symes, W. i Humphrey, N. (2011). The deployment, training and teacher relationships of teaching assistants supporting pupils with autistic spectrum disorders (ASD) in mainstream secondary schools. British Journal of Special Education, 38(2), 57-64. DOI: 10.1111/j.1467-8578.2011.00499.x

Symes, W. i Humphrey, N. (2012). Including pupils with autistic spectrum disorders in the classroom: the role of teaching assistants. European Journal of Special Needs Education, 27(4), 517-532. DOI: 10.1080/08856257.2012.726019 
Špelić, A. i Košeto, M. (2012). Preparation of an autistic child for school. Metodički obzori: časopis za odgojnoobrazovnu teoriju i praksu, 7(2), 157-172. DOI: doi.org/10.32728/mo.07.2.2012.13

Ustav Republike Hrvatske. Narodne novine, 85/10.

Versteeg, M. i Steendijk. (2019). Putting post-decision wagering to the test: a measure of self-perceived knowledge in basic sciences? Perspectives on Medical Education, 8, 9-16. DOI: 10.1007/s40037-019-0495-4

Webster, R. i Blatchford, P. (2015). Worlds apart? The nature and quality of the educational experiences of pupils with a statement for special educational needs in mainstream primary schools. British Educational Research Journal, 41(2), 324-342. DOI: 10.1002/berj.3144

Yaeda, J., Kundu, M. i Nishimura, S. (2013). Self-perceived knowledge and skills of job coaches in Japan. Work, 45, 279-285. DOI: 10.3233/WOR-131595

Zrilić, S. (2013). Djeca s posebnim potrebama u vrtiću i nižim razredima osnovne škole - priručnik za roditelje, odgojitelje i učitelje. Zadar: Sveučilište u Zadru. 